Article

\title{
Effect of Ag on Properties, Microstructure, and Thermostability of $\mathrm{Cu}-\mathrm{Cr}$ Alloy
}

\author{
Yuqing Sun ${ }^{1,2,3,4,+}$, Gaolei $X u^{4,5,+}$, Xue Feng ${ }^{3, *}$, Lijun Peng ${ }^{1,3, *}$, Guojie Huang ${ }^{1,3, *}$, \\ Haofeng Xie ${ }^{1,3}$, Xujun $\mathrm{Mi}^{1,3}$ and Xinhua Liu ${ }^{2,6,7}$ \\ 1 State Key Laboratory of Nonferrous Metals and Processes, GRIMAT Group Co., Ltd., Beijing 100088, China; \\ 13521565625@163.com (Y.S.); xie.haofeng@126.com (H.X.); sklcopper1967@163.com (X.M.) \\ 2 Key Laboratory for Advanced Materials Processing (MOE), University of Science and Technology Beijing, \\ Beijing 100083, China; liuxinhua18@163.com \\ 3 GRIMAT Engineering Institute Co., Ltd., Beijing 101407, China \\ 4 General Research Institute for Nonferrous Metals, Beijing 100088, China; xugaolei@126.com \\ 5 Zhejiang Libo Industrial Co., Ltd., Shaoxing 312050, China \\ 6 Beijing Laboratory of Metallic Materials and Processing for Modern Transportation, Beijing 100083, China \\ 7 Beijing Advanced Innovation Center for Materials Genome Engineering, University of Science and \\ Technology Beijing, Beijing 100083, China \\ * Correspondence: xue015@163.com (X.F.); penglijun198677@163.com (L.P.); huangguojie@grinm.com (G.H.) \\ + These authors contributed equally to this work.
}

Received: 9 November 2020; Accepted: 23 November 2020; Published: 27 November 2020

check for updates

\begin{abstract}
Cu}-\mathrm{Cr}$-based alloys exhibit excellent electrical conductivity and strength, but their poor thermal stability limits their application in industry. In this paper, $\mathrm{Cu}-0.2 \mathrm{Cr}$ (at. \%) and $\mathrm{Cu}-0.2 \mathrm{Cr}-0.12 \mathrm{Ag}$ (at. \%) alloys were prepared to study the effect of $\mathrm{Ag}$ on the properties, microstructure, and thermal stability of the $\mathrm{Cu}-\mathrm{Cr}$ alloy. Microstructure and precipitation were observed by an optical microscope (OM) and a transmission-electron microscope (TEM). After cold-drawing by $99.9 \%$ and aging at $450{ }^{\circ} \mathrm{C}$ for $2 \mathrm{~h}$, the peak hardness and electric conductivity of the $\mathrm{Cu}-\mathrm{Cr}$ alloy were 120.3 HV and 99.5\% IACS, respectively, and those of the $\mathrm{Cu}-\mathrm{Cr}-\mathrm{Ag}$ alloy were $135.8 \mathrm{HV}$ and $98.3 \%$ IACS, respectively. The softening temperature of the $\mathrm{Cu}-\mathrm{Cr}$ alloy was $500 \sim 525^{\circ} \mathrm{C}$, and that of the $\mathrm{Cu}-\mathrm{Cr}-\mathrm{Ag}$ alloy was about $550^{\circ} \mathrm{C}$. The creep strains of the $\mathrm{Cu}-\mathrm{Cr}$ and $\mathrm{Cu}-\mathrm{Cr}-\mathrm{Ag}$ alloys at $40 \mathrm{MPa}$ and $400{ }^{\circ} \mathrm{C}$ for $50 \mathrm{~h}$ were $0.18 \%$ and $0.05 \%$, respectively. Ag elements improved the thermal stability of the $\mathrm{Cu}-\mathrm{Cr}$ alloy. Recovery and recrystallization occurred before the coarsening of precipitates during the softening process. Ag atoms mainly improved the softening resistance of the alloy by delaying recrystallization, and mainly increased creep resistance by preventing the increase in mobile-dislocation density.
\end{abstract}

Keywords: $\mathrm{Cu}-\mathrm{Cr}$ system alloy; aging process; microstructure; thermal stability; physical properties

\section{Introduction}

$\mathrm{Cu}-\mathrm{Cr}$-based alloys are typical precipitation-strengthening alloys with good electrical conductivity and mechanical properties, and they are used in integrated-circuit lead frames, connectors, and electrical equipment [1-5]. These alloys include $\mathrm{Cu}-\mathrm{Cr}-\mathrm{Zr}$ [6], $\mathrm{Cu}-\mathrm{Cr}-\mathrm{Zr}-\mathrm{Mg}$ [7], $\mathrm{Cu}-\mathrm{Cr}-\mathrm{Ag}$ [8], and $\mathrm{Cu}-\mathrm{Cr}-\mathrm{Mg}$ [9]. The electronic and crystal structures of $\mathrm{Ag}$ atoms are like those of $\mathrm{Cu}$; thus, the conductivity of the alloy decreases only slightly. In addition, a small number of $\mathrm{Ag}$ elements are readily soluble in the $\mathrm{Cu}$ matrix under atmospheric smelting [10], and lead to obvious solid-solution strengthening [11] and precipitation strengthening [12], so the $\mathrm{Cu}-\mathrm{Cr}-\mathrm{Ag}$ alloy interests many researchers. 
Liu et al. [8] reported that the strength and conductivity of the $\mathrm{Cu}-0.13 \mathrm{Cr}-0.074 \mathrm{Ag}$ alloy were $473 \mathrm{MPa}$ and $94.5 \%$ IACS, respectively, after solution-treating at $870{ }^{\circ} \mathrm{C}$ for $1 \mathrm{~h}$, cold rolling (CR) by $60 \%$, and aging at $480{ }^{\circ} \mathrm{C}$ for $2 \mathrm{~h}$. The Ag element was uniformly distributed in the $\mathrm{Cu}$ matrix. The structure of $\mathrm{Cr}$ phases in the alloy was transformed from face-centered cubic (fcc) to body-centered cubic (bcc), and the orientation relationship between $\mathrm{Cr}$ precipitates and matrix was transformed from cube-on-cube to $\mathrm{N}-\mathrm{W}$. Xu et al. [11] determined that the optimal content of Ag in the $\mathrm{Cu}-0.91 \mathrm{Cr}$ alloy was $0.11 \mathrm{wt} \%$ according to the properties of the alloy and the price of silver. Insoluble $\mathrm{Cr}$ phases during casting were decreased and spheroidized with increasing Ag content, leading to better alloy properties. Islamgaliev et al. [12] improved the tensile strength of the $\mathrm{Cu}-0.5 \mathrm{Cr}-0.12 \mathrm{Ag}-0.06 \mathrm{Fe}-0.06 \mathrm{P}-0.05 \mathrm{Si}$ alloy to $845 \mathrm{MPa}$ through severe plastic deformation, and electrical conductivity remained at $81 \%$ IACS. Yuan et al. [13] confirmed that dynamic recrystallization [14,15] occurred in the $\mathrm{Cu}-\mathrm{Cr}-\mathrm{Ag}$ alloy during updrawing continuous casting, and average grain size decreased, thus enhancing the mechanical properties of the alloy. Watanabe et al. [16] confirmed that $0.1 \mathrm{wt} \% \mathrm{Ag}$ reduced the interprecipitate spacing of the $\mathrm{Cr}$ phase in the $\mathrm{Cu}-0.5 \mathrm{Cr}$ alloy and inhibited recovery during aging, thus improving strength. To summarize, studies on the $\mathrm{Cu}-\mathrm{Cr}-\mathrm{Ag}$ alloy mainly focused on the preparation process, mechanical properties, and microstructure, but less on thermal stability. Mahmadi et al. [17] studied the creep properties of the $\mathrm{Cu}-0.3 \mathrm{Cr}-0.1 \mathrm{Ag}$ alloy in the aging and deformation states, and reported that the aging alloy showed better creep resistance due to more $\mathrm{Cr}$ precipitates, but the creep process of the $\mathrm{Cu}-\mathrm{Cr}$ alloy affected by the Ag element was not explored. Yuan et al. [18] determined that the softening temperature of the $\mathrm{Cu}-0.19 \mathrm{Cr}-0.08 \mathrm{Ag}$ alloy was $550 \sim 600{ }^{\circ} \mathrm{C}$, which was ascribed to the $\mathrm{Cr}$ precipitates impeding the movement of dislocation. However, the softening mechanism of the alloy and how $\mathrm{Ag}$ affected the softening process of the $\mathrm{Cu}-\mathrm{Cr}$ alloy were not clear. Therefore, it was necessary to explore the effect of $\mathrm{Ag}$ on the microstructure, mechanical properties, and thermal stability of the $\mathrm{Cu}-\mathrm{Cr}$ alloy.

In this paper, the mechanical properties, softening properties, and creep properties of $\mathrm{Cu}-0.2 \mathrm{Cr}$ (at. \%) and $\mathrm{Cu}-0.2 \mathrm{Cr}-0.12 \mathrm{Ag}$ (at. \%) were tested. Microstructure evolution during the softening and creep process was analyzed, and the mechanism of $\mathrm{Ag}$ on the mechanical properties and thermal stability of the $\mathrm{Cu}-\mathrm{Cr}$ alloy was explored.

\section{Materials and Methods}

Table 1 lists the chemical compositions of the alloys in this study. Raw materials were composed of a $99.99 \%$ high-purity cathode copper $\mathrm{Cu}-5 \% \mathrm{Cr}$ (wt \%) master alloy and pure silver. Materials were melted at $1200^{\circ} \mathrm{C}$ in an argon atmosphere by a ZG0025 vacuum medium-frequency induction furnace (Shanghai Chenhua Technology Co., Ltd., Shanghai, China) and homogenized at $900{ }^{\circ} \mathrm{C}$ for $12 \mathrm{~h}$ followed by water quenching. The homogenized samples were cold-drawn by $99.9 \%$ deformation and aged at $450{ }^{\circ} \mathrm{C}$ for different times to determine the best comprehensive properties. After peak aging treatment, the samples were annealed at $300 \sim 700{ }^{\circ} \mathrm{C}$ for $1 \mathrm{~h}$ to measure the softening temperature of the $\mathrm{Cu}-\mathrm{Cr}$ and $\mathrm{Cu}-\mathrm{Cr}-\mathrm{Ag}$ alloys. The creep properties of the alloys were tested at 400 and $500^{\circ} \mathrm{C}$ for $50 \mathrm{~h}$ with a load of $40 \mathrm{MPa}$.

Table 1. Chemical compositions of studied alloys.

\begin{tabular}{cccc}
\hline \multirow{2}{*}{ Nominal Composition (at. \%) } & \multicolumn{4}{c}{ Analyzed Composition (at. \%) } \\
\cline { 2 - 4 } & $\mathrm{Cr}$ & $\mathrm{Ag}$ & $\mathbf{C u}$ \\
\hline $\mathrm{Cu}-0.2 \mathrm{Cr}$ & 0.2 & $/$ & $\mathrm{Bal}$ \\
$\mathrm{Cu}-0.2 \mathrm{Cr}-0.12 \mathrm{Ag}$ & 0.2 & 0.12 & $\mathrm{Bal}$. \\
\hline
\end{tabular}

Hardness was measured by a 430 SVD-type Vickers hardness tester (Beijing Huahai Henghui Technology Co., Ltd., Beijing, China) with $5 \mathrm{~kg}$ loading and a holding time of $15 \mathrm{~s}$. Electrical conductivity was tested by a Sigma 2008 digital eddy current conductivity meter with $500 \mathrm{KHz}$. Each value was measured 5 times, and the average value was taken. Creep properties were measured by an RD-50 high-temperature creep-testing machine. The microstructure and precipitates of the alloys were 
observed by an Axiovert 200MAT (Guangdong Jingpu Industrial Co., Ltd., Guangdong, China) optical microscope (OM) and FEI Tecnai G ${ }^{2}$ F20 (FEI, Hillsboro, OR, USA) electronic microscope. The samples for transmission-electron-microscope (TEM) observation were prepared by electrolytic polishing; the ratio of nitric acid to methanol was 1:4.

\section{Results}

\subsection{Properties}

\subsubsection{Mechanical Properties}

Figure 1 shows the hardness and conductivity of the $\mathrm{Cu}-\mathrm{Cr}$ and $\mathrm{Cu}-\mathrm{Cr}-\mathrm{Ag}$ alloys at $450{ }^{\circ} \mathrm{C}$. As shown in Figure 1a, compared with $\mathrm{Cu}-\mathrm{Cr}$, the $\mathrm{Cu}-\mathrm{Cr}-\mathrm{Ag}$ alloy showed higher hardness at the same aging time. The hardness of the two alloys increased rapidly and then decreased after reaching the peak value. The peak hardness of $\mathrm{Cu}-\mathrm{Cr}$ reached $120.3 \mathrm{Hv}$ after aging for $2 \mathrm{~h}$, while that of the $\mathrm{Cu}-\mathrm{Cr}-\mathrm{Ag}$ alloy reached $135.8 \mathrm{Hv}$ after aging for $4 \mathrm{~h}$, and the decreasing trend was slower. When aging time was $16 \mathrm{~h}$, the hardness of the $\mathrm{Cu}-\mathrm{Cr}$ alloy was only $90 \mathrm{Hv}$, which was $30 \mathrm{Hv}$ less than that at the peak aging state, and the hardness of the $\mathrm{Cu}-\mathrm{Cr}-\mathrm{Ag}$ alloy was $130 \mathrm{Hv}$, which was only $5 \mathrm{Hv}$ less than that of the peak aging condition. The result illustrated that the hardness and stability of the mechanical properties of the $\mathrm{Cu}-\mathrm{Cr}$ alloy improved with Ag elements. The conductivity of both alloys rapidly increased and gradually stabilized, as shown in Figure 1b. Compared with cold-rolled alloys, the conductivity of the $\mathrm{Cu}-\mathrm{Cr}$ and $\mathrm{Cu}-\mathrm{Cr}-\mathrm{Ag}$ alloys aged for $2 \mathrm{~h}$ increased by $13.1 \%$ and 9.8\% IACS, respectively. Electrical conductivity corresponding to the peak hardness of the $\mathrm{Cu}-\mathrm{Cr}$ and $\mathrm{Cu}-\mathrm{Cr}-\mathrm{Ag}$ alloys was $99.5 \%$ and $98.3 \%$ IACS, respectively.
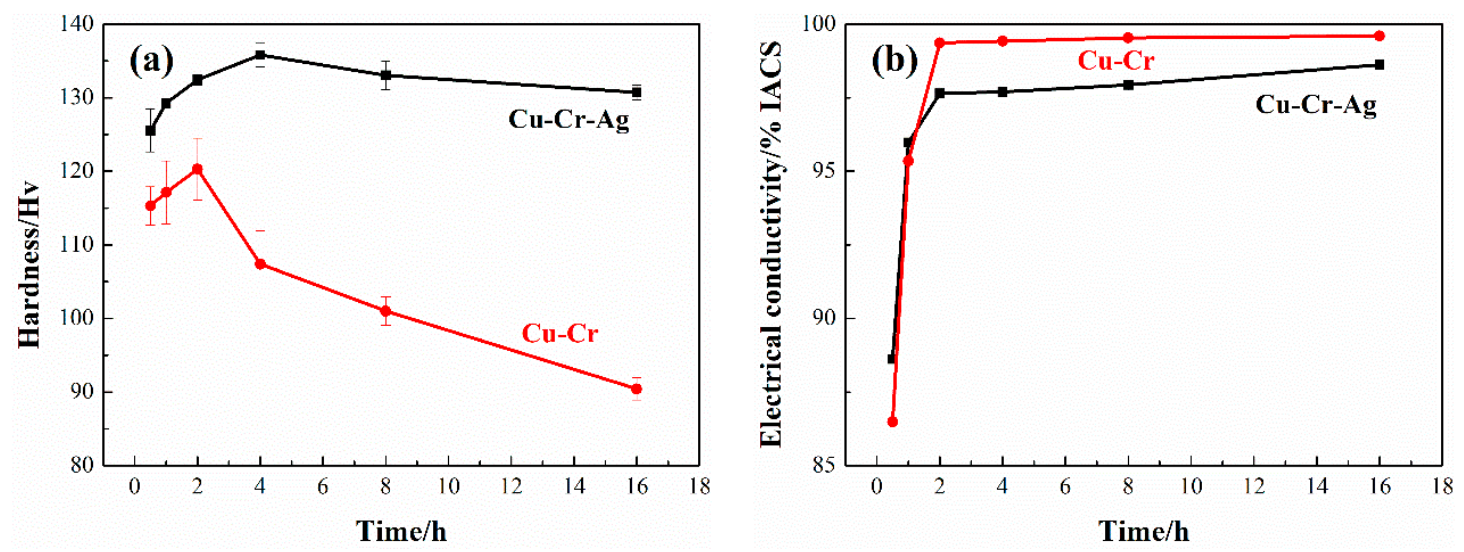

Figure 1. (a) Hardness and (b) electrical conductivity of alloys at $450{ }^{\circ} \mathrm{C}$.

\subsubsection{Softening Resistance}

Figure 2 presents the change in hardness of the alloys after $1 \mathrm{~h}$ incubation at different annealing temperatures. The hardness of the two alloys slightly increased and then decreased with the rise of temperature. According to GB/T 33370-2016, the softening temperature of copper and copper alloys is defined as the temperature corresponding to hardness dropping to $80 \%$ of the original hardness. The hardness of the $\mathrm{Cu}-\mathrm{Cr}$ binary alloy that annealed at $500{ }^{\circ} \mathrm{C}$ was $123.5 \mathrm{HV}$, which rapidly decreased to $88.9 \mathrm{Hv}$ at $550{ }^{\circ} \mathrm{C}$, namely, $74 \%$ of the peak-aging hardness. This indicated that the softening temperature of the $\mathrm{Cu}-\mathrm{Cr}$ alloy was $500 \sim 525{ }^{\circ} \mathrm{C}$. The hardness of the $\mathrm{Cu}-\mathrm{Cr}-\mathrm{Ag}$ alloy at $550{ }^{\circ} \mathrm{C}$ was $110.4 \mathrm{HV}$, which is about $80 \%$ of the peak-aging hardness. Therefore, softening temperature was about $550{ }^{\circ} \mathrm{C}$, which was higher than that of the $\mathrm{Cu}-\mathrm{Cr}$ alloy. 


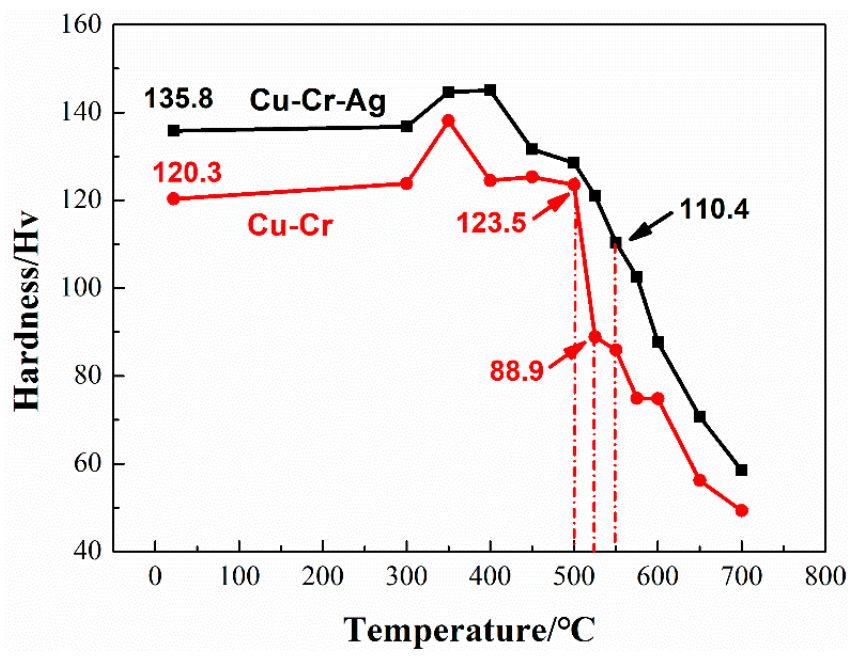

Figure 2. Hardness of test alloys at different annealing temperature levels for $1 \mathrm{~h}$.

\subsubsection{Creep Resistance}

The creep curves of both alloys at 400 and $500{ }^{\circ} \mathrm{C}$ are shown in Figure 3. Under the same loading stress, the creep curves of the two alloys showed the same trend, namely, strain positively rose with loading time. Strain also rose with an increase in temperature. The creep strain of the $\mathrm{Cu}-0.2 \mathrm{Cr}$ alloy was $0.18 \%$ after loading at $400{ }^{\circ} \mathrm{C}$ for $50 \mathrm{~h}$, and that of the $\mathrm{Cu}-0.2 \mathrm{Cr}-0.12 \mathrm{Ag}$ alloy was $0.05 \%$. However, the creep strain of the $\mathrm{Cu}-\mathrm{Cr}$ alloy obviously changed as temperature rose to $500{ }^{\circ} \mathrm{C}$. When loading time was increased to $35 \mathrm{~h}$, a creep fracture occurred in the $\mathrm{Cu}-\mathrm{Cr}$ alloy, but the creep stress of the $\mathrm{Cu}-\mathrm{Cr}-\mathrm{Ag}$ alloy was only $1.3 \%$ after $50 \mathrm{~h}$. Data illustrated that the Ag element improved the thermal stability of the $\mathrm{Cu}-0.2 \mathrm{Cr}$ alloy, which was consistent with the results in Figure 2.
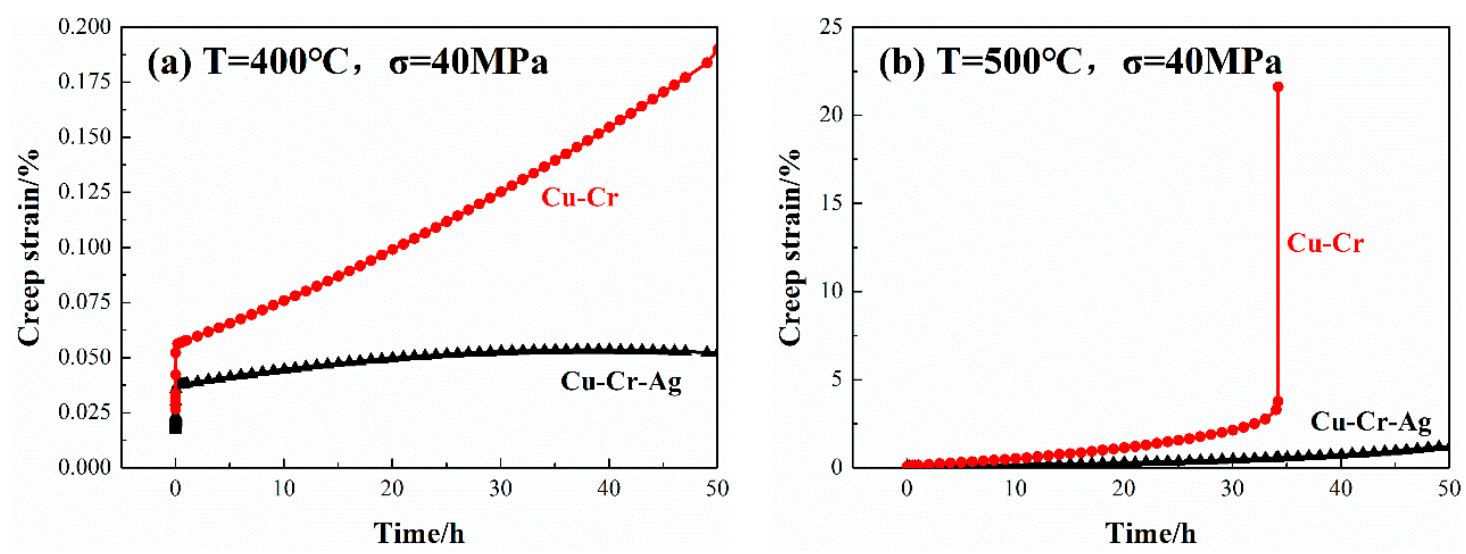

Figure 3. Creep curves of alloys at (a) 400 and (b) $500{ }^{\circ} \mathrm{C}$ under $40 \mathrm{MPa}$ stress.

\subsection{Microstructure}

Figure 4 shows the morphologies and selected-area electron-diffraction (SAED) pattern of the peak-aged alloys. Figure 4a shows that high-density dislocations formed in the $\mathrm{Cu}-\mathrm{Cr}$ alloy that displayed a morphology of mutual entanglement. In addition, many dispersed nanoscale-precipitate phases existed in the $\mathrm{Cu}$ matrix, and their morphologies included coffee-bean contrast and Moiré fringe contrast, as presented in Figure $4 \mathrm{~b}$. According to previous studies, the precipitate with coffee-bean contrast was a $\mathrm{Cr}$ phase with fcc structure [19-22]. Figure 4c,d show the selected-area diffraction-electron and schematic diagrams of the $\{001\}_{\mathrm{Cu}}$ direction, respectively. Two sets of diffraction spots occurred near the $\mathrm{Cu}$ matrix spots. One set was the diffraction of $0^{\circ}, 30^{\circ}$, and $60^{\circ}$ to the $\langle 011\rangle_{\mathrm{Cu}}$ direction of the matrix, and the other was a circle of diffraction spots near the center. According 
to previous studies $[23,24]$, diffraction spots around $\{022\}_{\mathrm{Cu}}$ in the matrix were the $\mathrm{Cr}$ phase with a bcc structure. Therefore, precipitates with Moiré fringe contrast were bcc $\mathrm{Cr}$, according to the morphology characteristics and distribution orientation of precipitates in Figure $4 \mathrm{~b}$. The Moiré contrast was caused by the superposition of the precipitates and double diffraction between precipitate phase and matrix $[19,25]$. The orientation relationship with $\left\langle 001>_{\mathrm{Cr}} \|<110>_{\mathrm{Cu}}\right.$ existed between $\mathrm{Cr}$ phase and matrix, namely, an N-W orientation relationship. Many intertwined dislocations were found in the $\mathrm{Cu}-\mathrm{Cr}-\mathrm{Ag}$ alloy, as shown in Figure 4e, which were the same in the $\mathrm{Cu}-\mathrm{Cr}$ alloy. Compared with Figure $4 b, f, A g$ elements did not change the microstructure of $\mathrm{Cr}$ precipitates, but inhibited the growth of $\mathrm{Cr}$ precipitates.
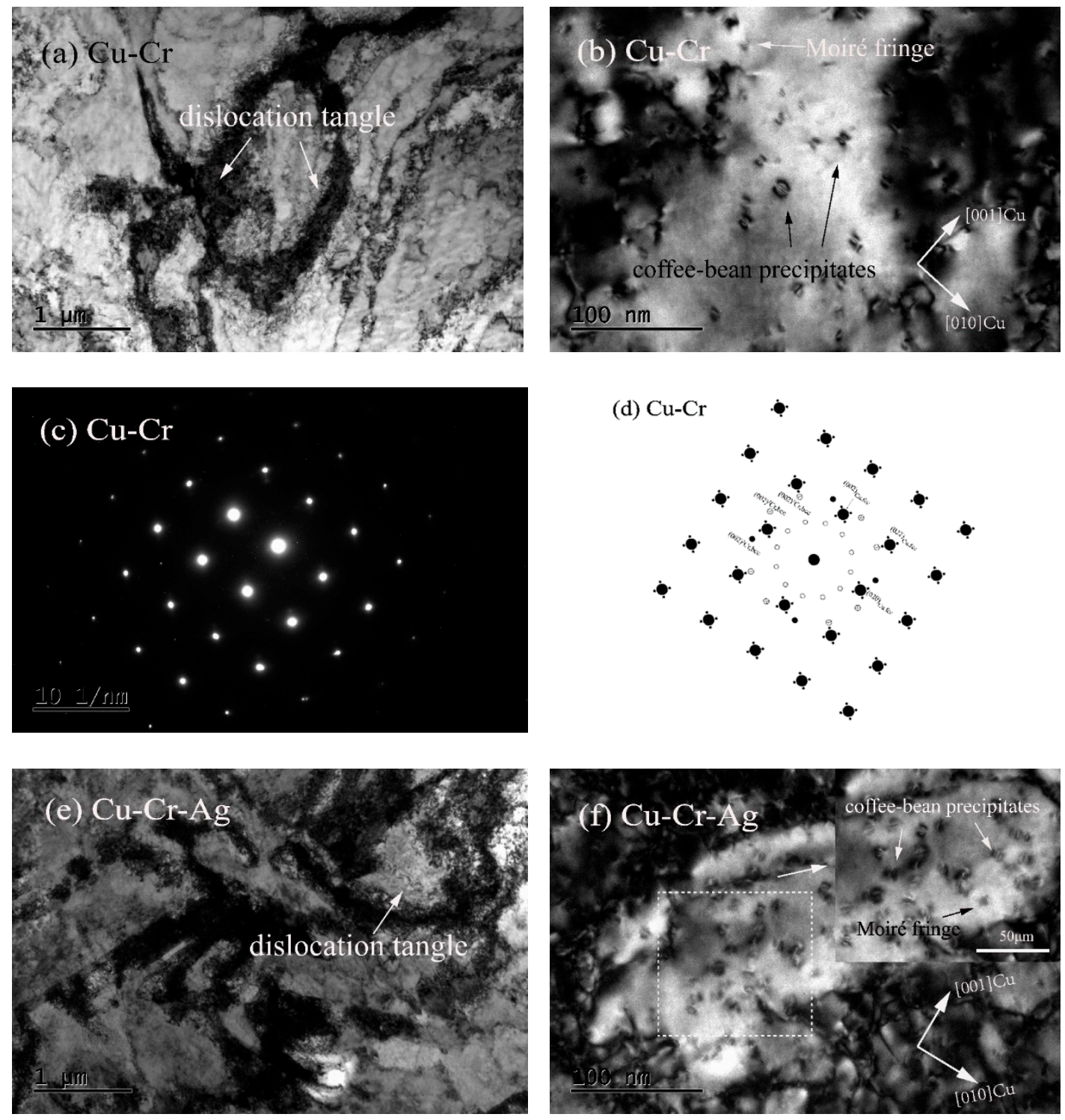

Figure 4. Morphologies and selected-area electron-diffraction (SAED) pattern of peak-aged alloys. (a,b) Bright-field image of $\mathrm{Cu}-\mathrm{Cr}$ alloy with zone axis of $(001)_{\mathrm{Cu}}$; (c) SAED pattern of (b); (d) schematic diagram of $(\mathbf{c}) ;(\mathbf{e}, \mathbf{f})$ bright-field image of $\mathrm{Cu}-\mathrm{Cr}$ alloy with zone axis of $(001)_{\mathrm{Cu}}$.

Figure 5 shows the microstructure of alloys after annealing at different temperature levels for $1 \mathrm{~h}$. As shown in Figure 5a,e, the fiber structures existed after large plastic drawing deformation of the alloys. Recrystallization occurred in the $\mathrm{Cu}-\mathrm{Cr}$ alloy at $500{ }^{\circ} \mathrm{C}$, as shown in Figure $5 \mathrm{~b}$, which was accelerated with rising annealing temperature, and the fiber structure eventually transformed into a recrystallized equiaxed structure, as shown in Figure 5d. The microstructure evolution of the 
$\mathrm{Cu}-\mathrm{Cr}-\mathrm{Ag}$ alloy during annealing was similar to that of the $\mathrm{Cu}-\mathrm{Cr}$ alloy, but $\mathrm{Ag}$ elements obviously inhibited the recrystallization of the alloy, which corresponded to the results in Figure 2.
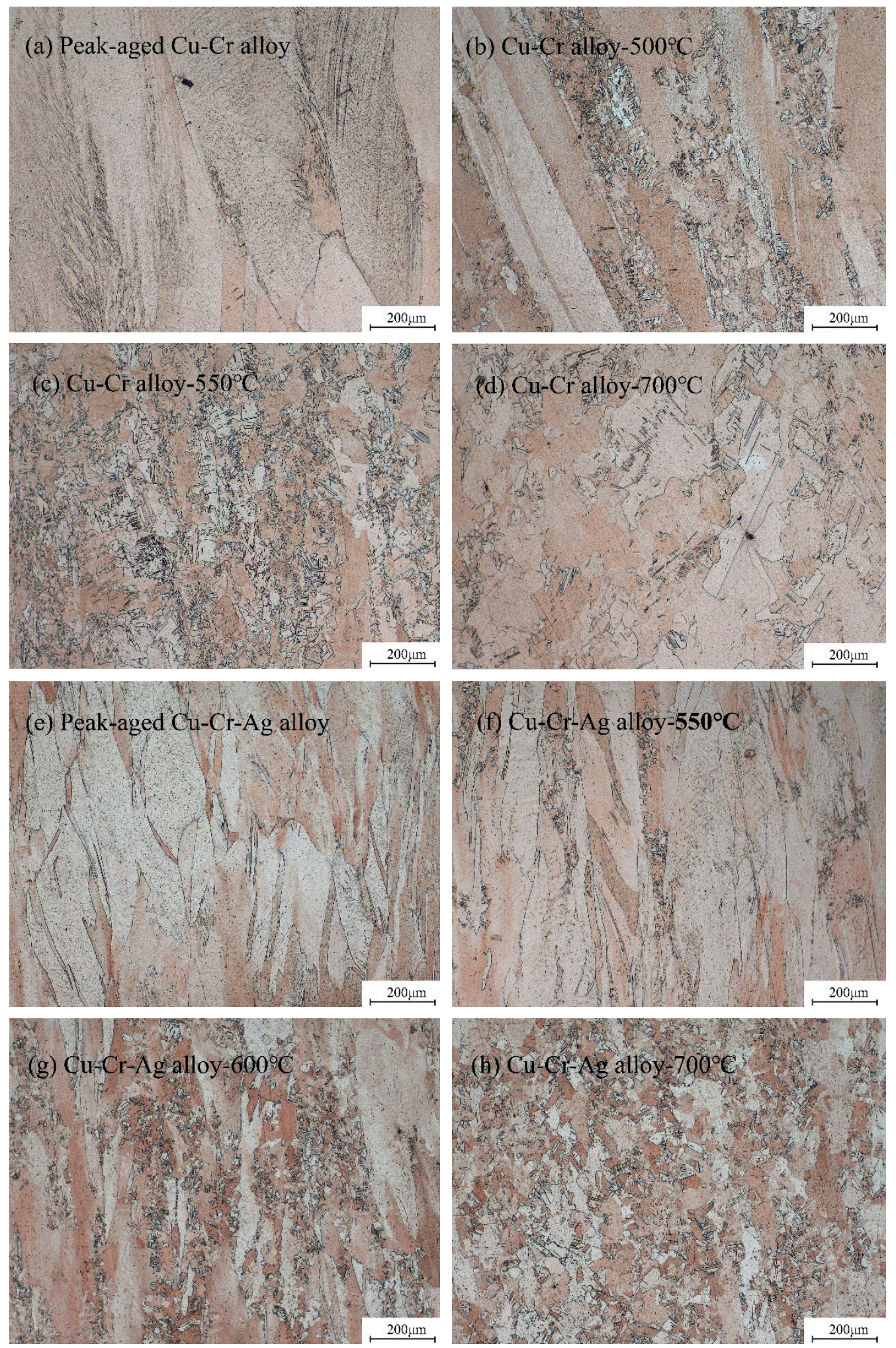

Figure 5. Microstructures of $(\mathbf{a}-\mathbf{d}) \mathrm{Cu}-\mathrm{Cr}$ and $(\mathbf{e}-\mathbf{h}) \mathrm{Cu}-\mathrm{Cr}-\mathrm{Ag}$ alloys annealed at different temperature levels for $1 \mathrm{~h}$. 
The TEM microstructures of both alloys at different annealing temperature levels for $1 \mathrm{~h}$ are shown in Figure 6. Subgrains, and fine and dispersed $\mathrm{Cr}$ precipitates were found in the $\mathrm{Cu}-0.2 \mathrm{Cr}$ alloy at $500{ }^{\circ} \mathrm{C}$, as shown in Figure $6 a, b$, and the size of the precipitated phase was consistent with that in the peak aging state. As temperature rose to $700{ }^{\circ} \mathrm{C}$, dislocation density decreased, obvious recrystallized grains existed in the $\mathrm{Cu}-\mathrm{Cr}$ matrix, and precipitates coarsened, as shown in Figure $6 \mathrm{c}, \mathrm{d}$. Recrystallization of the $\mathrm{Cu}-\mathrm{Cr}-\mathrm{Ag}$ alloy occurred at $600^{\circ} \mathrm{C}$. The size of $\mathrm{Cr}$ precipitates did not significantly increase, but recrystallized grains grew, and precipitates obviously coarsened at $700{ }^{\circ} \mathrm{C}$. Therefore, the softening of the $\mathrm{Cu}-\mathrm{Cr}$ and $\mathrm{Cu}-\mathrm{Cr}-\mathrm{Ag}$ alloys was accompanied by the recovery, recrystallization, grain growth, and coarsening of precipitates.
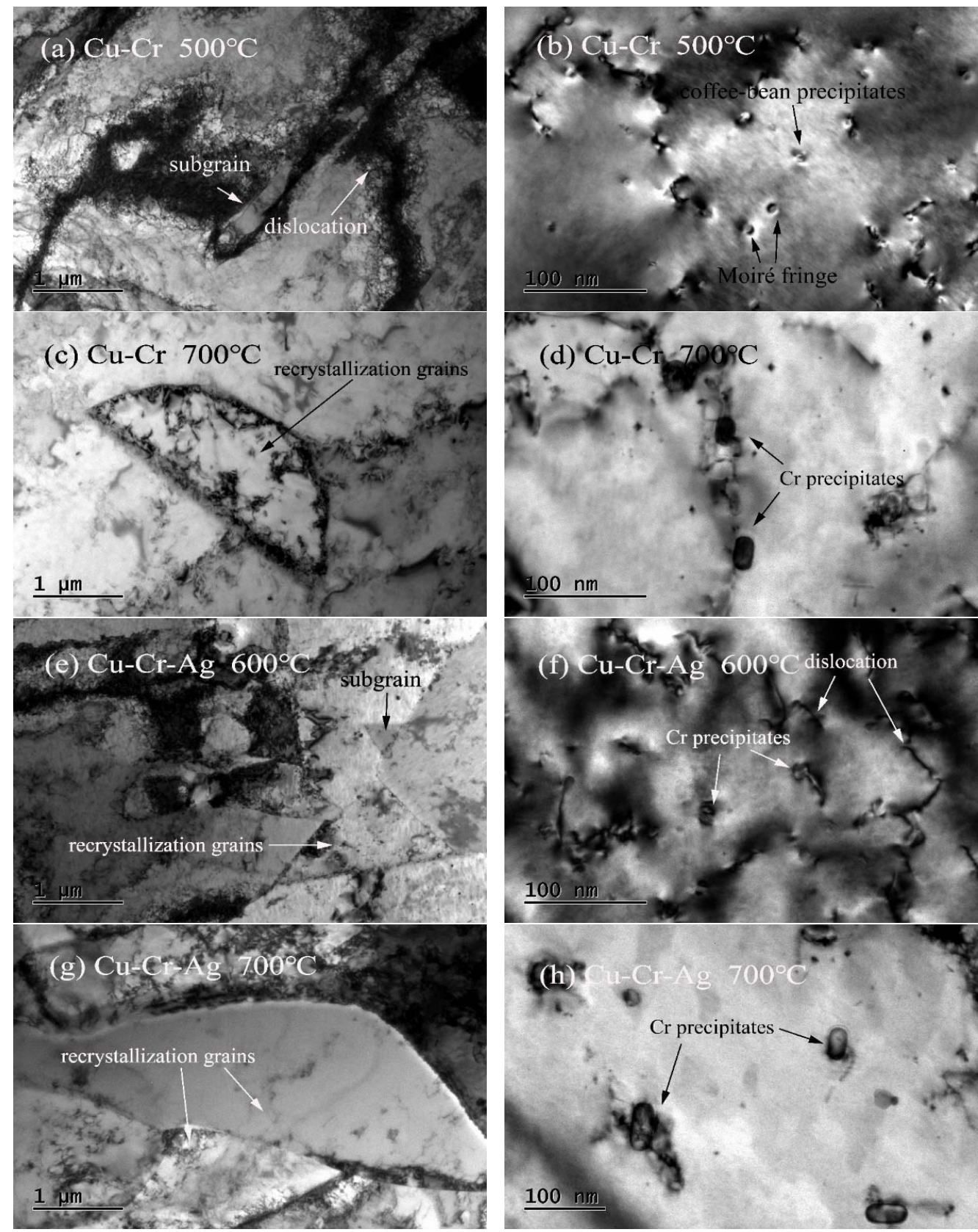

Figure 6. Microstructures of both alloys after holding for $1 \mathrm{~h}$ at different annealing temperature levels. Bright-field images of (a-d) $\mathrm{Cu}-\mathrm{Cr}$ and $(\mathbf{e}-\mathbf{h}) \mathrm{Cu}-\mathrm{Cr}-\mathrm{Ag}$ alloys. 
Figure 7 shows the microstructures of both alloys after a creep test at $500{ }^{\circ} \mathrm{C}$. Recrystallization was found in the $\mathrm{Cu}-\mathrm{Cr}$ alloy in Figure 7a, indicating that it occurred during the creep at a stress of $40 \mathrm{MPa}$ and temperature of $500{ }^{\circ} \mathrm{C}$. Meanwhile, dislocations were rearranged during the creep formed subgrain boundaries and absorbed by grain boundaries, which greatly reduced dislocation density in the matrix. Many precipitates existed in the matrix, which obviously interacted with the dislocations, as shown in Figure $7 b, c$. Precipitates can be divided into two types: the original precipitates of 20 to $30 \mathrm{~nm}$, and precipitates of 10 to $15 \mathrm{~nm}$ that formed during creep process. Creep strain increased with loading time, which promoted the movement of dislocations and the formation of new dislocations. Therefore, the interaction between dislocations and precipitates became more serious, resulting in stress concentration, the forming of crack sources, and the acceleration of the generation of creep cracks. These eventually led to the $\mathrm{Cu}-\mathrm{Cr}$ alloy fracturing at $35 \mathrm{~h}$. In addition, according to the morphology characteristics of the precipitates in Figure $7 d$, precipitates in the matrix were of bcc Cr phase with Moire fringe contrast, indicating that the precipitate structure eventually changed from fcc to bcc during the creep of the $\mathrm{Cu}-\mathrm{Cr}$ alloy. This was attributed to the fact that the creep is a thermal-activation process, so energy and structure develop in the stablest fashion. The mobile-dislocation density of the $\mathrm{Cu}-\mathrm{Cr}-\mathrm{Ag}$ alloy was significantly lower than that of the $\mathrm{Cu}-\mathrm{Cr}$ alloy. The morphology characteristics of precipitates in the $\mathrm{Cu}-\mathrm{Cr}-\mathrm{Ag}$ alloy were similar to those of the $\mathrm{Cu}-\mathrm{Cr}$ alloy, but average size was slightly larger.
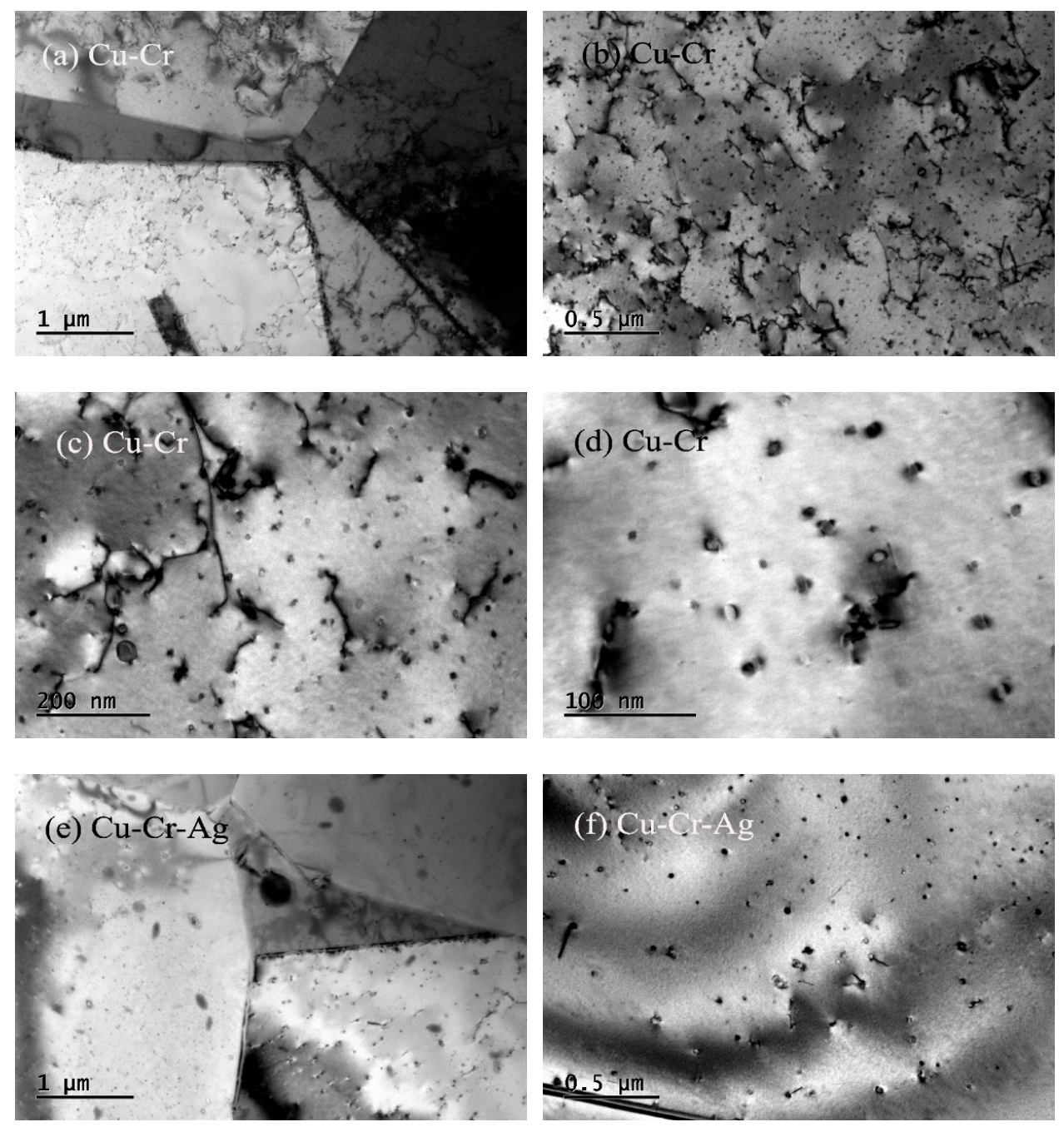

Figure 7. Cont. 

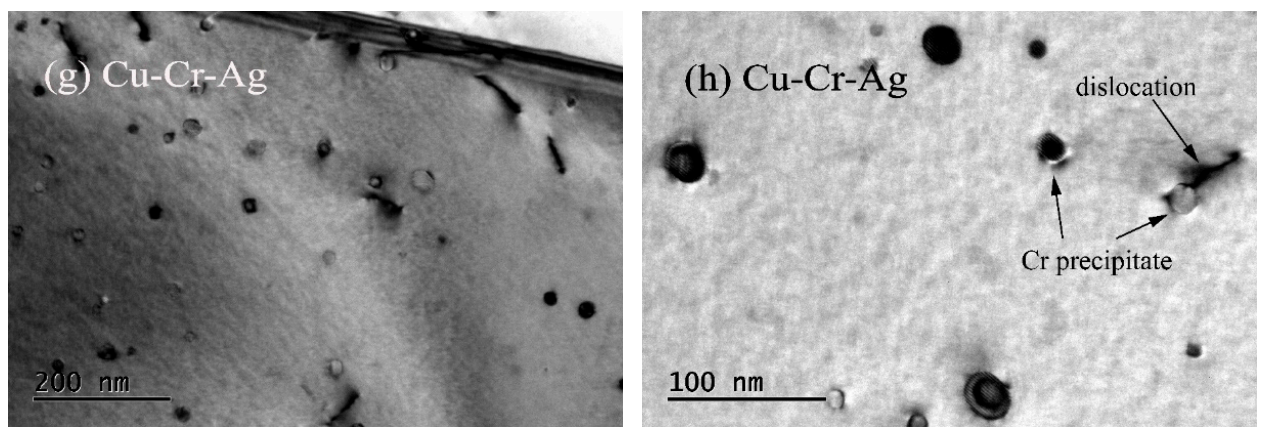

Figure 7. Microstructures of alloys after creep test at $500{ }^{\circ} \mathrm{C}$. Bright-field images of $(\mathbf{a}-\mathbf{d}) \mathrm{Cu}-\mathrm{Cr}$ and (e-h) $\mathrm{Cu}-\mathrm{Cr}-\mathrm{Ag}$ alloys.

\section{Discussion}

The hardness of the $\mathrm{Cu}-0.2 \mathrm{Cr}$ alloy was improved by 0.12 at. \% $\mathrm{Ag}$, shown in Figure 1 . This was attributed to Ag elements in the matrix playing a role in solution strengthening, hindering the growth of precipitates (Figure 4), and reducing interprecipitate spacing [16]. In addition, Ag elements reduced the stacking-fault energy of the copper alloy [26] and increased dislocation density, thus enhancing the mechanical properties of the $\mathrm{Cu}-\mathrm{Cr}$ alloy. The aging time of the $\mathrm{Cu}-\mathrm{Cr}$ alloy reaching peak value was prolonged by $\mathrm{Ag}$, which was ascribed to $\mathrm{Ag}$ inhibiting the growth of precipitates [27,28].

The recovery, recrystallization, and coarsening of precipitates occurred in the softening process of the test alloys, as shown in Figures 5 and 6. When the alloys were annealed near the softening temperature, recovery and recrystallization occurred in the two alloys, but precipitates barely coarsened. As annealing temperature was increased to $700{ }^{\circ} \mathrm{C}$, the diffusion rate of atoms rapidly increased [29], resulting in the precipitates of the two alloys obviously coarsening. Therefore, the recovery and recrystallization of the alloys occurred prior to precipitation coarsening during softening of the alloys. The softening resistance of the $\mathrm{Cu}-0.2 \mathrm{Cr}$ alloy improved by adding 0.1 at. \% Ag (Figure 2), which was attributed to $\mathrm{Ag}$ atoms raising the recrystallization activation energy of the copper alloy [30] and delaying recrystallization during softening (Figure 5). Meanwhile, the Ag elements had little effect on the precipitates (Figure 6), indicating that recrystallization was the main factor that caused alloy softening.

The addition of 0.12 at. \% Ag elements also improved the creep resistance of $\mathrm{Cu}-0.2 \mathrm{Cr}$ (Figure 3). The creep process was accompanied by changes in grains, dislocations, and precipitates. Recrystallization occurred in the $\mathrm{Cu}-\mathrm{Cr}$ and $\mathrm{Cu}-\mathrm{Cr}-\mathrm{Ag}$ alloys after the creep test at $500{ }^{\circ} \mathrm{C}$ with a stress of $40 \mathrm{MPa}$, and the dislocation density of $\mathrm{Cu}-\mathrm{Cr}$ was higher than that of the $\mathrm{Cu}-\mathrm{Cr}-\mathrm{Ag}$ alloy (Figure 6). This was attributed to complex dislocation changes during the creep. Plastic deformation caused an increment of dislocation density in early deformation, and the dislocations in different slip systems interacted to form dislocation entanglement and cells. The dislocation cells rearranged to form a subgrain boundary with the increase in creep strain. In addition, precipitates gradually coarsened during the creep, which reduced the pinning force of dislocation and resulted in the substructure evolving into a recrystallized structure. Compared with the $\mathrm{Cu}-\mathrm{Cr}$ alloy, the size of precipitates in the $\mathrm{Cu}-\mathrm{Cr}-\mathrm{Ag}$ alloy was larger after the creep test, which may be attributed to Ag hindering the increase in dislocation density during creep and reducing the interaction between precipitates and dislocations.

\section{Conclusions}

This work studied the mechanical properties, thermal stability, and microstructure of the $\mathrm{Cu}-0.2 \mathrm{Cr}$ (at. \%) and $\mathrm{Cu}-0.2 \mathrm{Cr}-0.12-\mathrm{Ag}$ (at. \%) alloys. Results are summarized as follows:

1. The addition of 0.12 at. \% $\mathrm{Ag}$ increased the hardness of the $\mathrm{Cu}-0.2 \mathrm{Cr}$ alloy and slightly decreased electrical conductivity. The peak hardness of the $\mathrm{Cu}-0.2 \mathrm{Cr}$ alloy was $120.3 \mathrm{Hv}$ after aging at $450{ }^{\circ} \mathrm{C}$ for $2 \mathrm{~h}$, while that of the $\mathrm{Cu}-\mathrm{Cr}-\mathrm{Ag}$ alloy reached $135.8 \mathrm{Hv}$ after aging at $450{ }^{\circ} \mathrm{C}$ for $4 \mathrm{~h}$. 
Electrical conductivity corresponding to the peak hardness of the $\mathrm{Cu}-0.2 \mathrm{Cr}$ and $\mathrm{Cu}-0.2 \mathrm{Cr}-0.12 \mathrm{Ag}$ alloys was $99.5 \%$ and $98.3 \%$ IACS, respectively.

2. The softening resistance of the $\mathrm{Cu}-0.2 \mathrm{Cr}$ alloy was improved by 0.12 at. \% Ag elements. The softening temperature of the $\mathrm{Cu}-0.2 \mathrm{Cr}$ alloy was $500 \sim 525^{\circ} \mathrm{C}$, and that of the $\mathrm{Cu}-0.2 \mathrm{Cr}-0.12 \mathrm{Ag}$ alloy was about $550^{\circ} \mathrm{C}$. The softening process was accompanied by the recovery, recrystallization, and coarsening of precipitates. Recovery and recrystallization occurred prior to the coarsening of precipitates. Ag elements inhibited the recrystallization of the $\mathrm{Cu}-\mathrm{Cr}$ alloy and had little effect on the precipitates.

3. The creep strains of the $\mathrm{Cu}-0.2 \mathrm{Cr}$ and $\mathrm{Cu}-0.2 \mathrm{Cr}-0.12 \mathrm{Ag}$ alloys at $40 \mathrm{MPa}$ and $400{ }^{\circ} \mathrm{C}$ for $50 \mathrm{~h}$ were $0.18 \%$ and $0.05 \%$, respectively. The creep strain of the $\mathrm{Cu}-0.2 \mathrm{Cr}$ alloy was significantly greater than that of the $\mathrm{Cu}-0.2 \mathrm{Cr}-0.12 \mathrm{Ag}$ alloy at $500{ }^{\circ} \mathrm{C}$. Alloy creep was accompanied by secondary precipitation of the $\mathrm{Cr}$ phase, dislocation slip, and recrystallization. The addition of 0.12 at. \% $\mathrm{Ag}$ increased the creep resistance of the $\mathrm{Cu}-0.2 \mathrm{Cr}$ alloy mainly by hindering the increase in mobile dislocation density.

Author Contributions: Conceptualization, L.P., G.H. and H.X.; formal analysis, G.X. and Y.S.; investigation, G.X.; original-draft preparation, Y.S.; writing-review and editing, Y.S. and L.P.; supervision, G.H., H.X., X.M., X.F. and X.L.; project administration, H.X. and X.M.; funding acquisition, H.X. and X.M. All authors have read and agreed to the published version of the manuscript.

Funding: This research was funded by the National Key R\&D Program of China (no.2016YFB0301400), the Natural Science Foundation of China (no. 51601017), and the Technological Innovation 2025 and Major Special project of NingBo (nos. 2018B10030 and 2019B10088).

Conflicts of Interest: The authors declare no conflict of interest.

\section{References}

1. Xu, G.-L.; Peng, L.-J.; Huang, G.-J.; Xie, H.-F.; Yang, Z.; Feng, X.; Yin, X.-Q.; Yang, Z. Microstructural evolution and properties of a $\mathrm{Cu}-\mathrm{Cr}-\mathrm{Ag}$ alloy during continuous manufacturing process. Rare Met. 2019, 1-8. [CrossRef]

2. Zhang, Y.; Sun, H.-L.; Volinsky, A.A.; Tian, B.-H.; Chai, Z.; Liu, P.; Liu, Y. Characterization of the Hot Deformation Behavior of $\mathrm{Cu}-\mathrm{Cr}-\mathrm{Zr}$ Alloy by Processing Maps. Acta Met. Sin. Engl. Lett. 2016, 29, 422-430. [CrossRef]

3. Sun, Y.; Peng, L.; Huang, G.; Feng, X.; Xie, H.; Mi, X.; Liu, X. Effect of Mg on the stress relaxation resistance of $\mathrm{Cu}-\mathrm{Cr}$ alloys. Mater. Sci. Eng. A 2021, 799, 140144. [CrossRef]

4. Huang, A.; Wang, Y.; Wang, M.; Song, L.; Li, Y.; Gao, L.; Huang, C.; Zhu, Y. Optimizing the strength, ductility and electrical conductivity of a Cu-Cr-Zr alloy by rotary swaging and aging treatment. Mater. Sci. Eng. A 2019, 746, 211-216. [CrossRef]

5. Feng, X.; Xie, H.; Li, Z.; Mi, X.; Huang, G.; Peng, L.; Yang, Z.; Yin, X. Comparison of Ag and Zr with same atomic ratio in Cu-Cr alloy. IOP Conf. Ser. Mater. Sci. Eng. 2018, 397, 012053. [CrossRef]

6. Batra, I.; Dey, G.; Kulkarni, U.; Banerjee, S. Microstructure and properties of a Cu-Cr-Zr alloy. J. Nucl. Mater. 2001, 299, 91-100. [CrossRef]

7. Cheng, J.; Yu, F.; Shen, B. Solute clusters and chemistry in a $\mathrm{Cu}-\mathrm{Cr}-\mathrm{Zr}-\mathrm{Mg}$ alloy during the early stage of aging. Mater. Lett. 2014, 115, 201-204. [CrossRef]

8. Liu, Y.; Li, Z.; Jiang, Y.; Zhang, Y.; Zhou, Z.; Lei, Q. The microstructure evolution and properties of a Cu-Cr-Ag alloy during thermal-mechanical treatment. J. Mater. Res. 2017, 32, 1324-1332. [CrossRef]

9. Sun, Y.; Peng, L.; Huang, G.; Xie, H.; Mi, X.; Liu, X. Effects of Mg addition on the microstructure and softening resistance of Cu-Cr alloys. Mater. Sci. Eng. A 2020, 776, 139009. [CrossRef]

10. Freudenberger, J.; Lyubimova, J.; Gaganov, A.; Witte, H.; Hickman, A.; Jones, H.; Nganbe, M. Non-destructive pulsed field CuAg-solenoids. Mater. Sci. Eng. A 2010, 527, 2004-2013. [CrossRef]

11. Xu, S.; Fu, H.; Wang, Y.; Xie, J. Effect of Ag addition on the microstructure and mechanical properties of Cu-Cr alloy. Mater. Sci. Eng. A 2018, 726, 208-214. [CrossRef]

12. Islamgaliev, R.K.; Sitdikov, V.D.; Nesterov, K.M.; Pankratov, D.L. Structure and crystallographic texture in the Cu-Cr-Ag alloy subjected to severe plastic deformation. Rev. Adv. Mater. Sci. 2014, 39, 61-68. 
13. Yuan, D.; Yang, B.; Chen, J.; Chen, H.; Zhang, J.; Wang, H. Upward Continuous Casting in the Manufacture of Cu-Cr-Ag Alloys: Potential for Enhancing Strength Whilst Maintaining Ductility. Met. Mater. Trans. A 2017, 48, 6083-6090. [CrossRef]

14. Cao, Y.; Li, Z.; Zhang, X.; Wang, Z.; Qi, L.; Zhao, H. Dynamic recrystallization behavior of upward continuous casting Cu-0.19Cr-0.1Ag alloy. Mater. Res. Express 2019, 6, 046547. [CrossRef]

15. Xu, G.; Mi, X.; Peng, L.; Huang, G.; Xie, H.; Yang, Z.; Feng, X.; Yin, X.; Xu, L.G. High-temperature deformation behavior of the Cu-0.21 Cr-0.12Ag alloy made by upward continuous casting. Mater. Res. Express 2019, 6, 046540. [CrossRef]

16. Watanabe, C.; Monzen, R.; Tazaki, K. Mechanical properties of $\mathrm{Cu}-\mathrm{Cr}$ system alloys with and without $\mathrm{Zr}$ and Ag. J. Mater. Sci. 2007, 43, 813-819. [CrossRef]

17. Mahmudi, R.; Karsaz, A.; Akbari-Fakhrabadi, A.; Geranmayeh, A.R. Impression creep study of a Cu-0.3Cr-0.1Ag alloy. Mater. Sci. Eng. A 2010, 527, 2702-2708. [CrossRef]

18. Peng, L.J.; Mi, X.J.; Xie, H.F.; Yu, Y.; Huang, G.J.; Yang, Z.; Feng, X.; Yin, X.Q. Microstructure and Properties of Cu-Cr-Zr-Ag Alloy. Mater. Sci. Forum 2018, 941, 1613-1617. [CrossRef]

19. Wang, K.; Liu, K.-F.; Zhang, J.-B. Microstructure and properties of aging Cu-Cr-Zr alloy. Rare Met. 2014, 33, 134-138. [CrossRef]

20. Cheng, J.; Shen, B.; Yu, F. Precipitation in a Cu-Cr-Zr-Mg alloy during aging. Mater. Charact. 2013, 81, 68-75. [CrossRef]

21. Chbihi, A.; Sauvage, X.; Blavette, D. Atomic scale investigation of Cr precipitation in copper. Acta Mater. 2012, 60, 4575-4585. [CrossRef]

22. Knights, R.W.; Wilkes, P. Precipitation of chromium in copper and copper-nickel base alloys. Met. Mater. Trans. A 1973, 4, 2389-2393. [CrossRef]

23. Peng, L.; Xie, H.; Huang, G.; Xu, G.; Yin, X.; Feng, X.; Mi, X.; Yang, Z. The phase transformation and strengthening of a Cu-0.71 wt\% Cr alloy. J. Alloy. Compd. 2017, 708, 1096-1102. [CrossRef]

24. Fujii, T.; Nakazawa, H.; Kato, M.; Dahmen, U. Crystallography and morphology of nanosized Cr particles in a Cu-0.2\% Cr alloy. Acta Mater. 2000, 48, 1033-1045. [CrossRef]

25. Yang, W.; Ji, S.; Wang, M.; Li, Z. Precipitation behaviour of Al-Zn-Mg-Cu alloy and diffraction analysis from $\eta^{\prime}$ precipitates in four variants. J. Alloy. Compd. 2014, 610, 623-629. [CrossRef]

26. Gallagher, P.C.J. The influence of alloying, temperature, and related effects on the stacking fault energy. Metall. Trans. 1970, 1, 2429-2461.

27. Tang, N.Y.; Taplin, D.M.R.; Dunlop, G.L. Precipitation and aging in high-conductivity Cu-Cr alloys with additions of zirconium and magnesium. Met. Sci. J. 2013, 1, 270-275. [CrossRef]

28. Jinshui, C.; Bin, Y.; Junfeng, W.; Xiao, X.; Huiming, C.; Hang, W. Effect of different Zr contents on properties and microstructure of Cu-Cr-Zr alloys. Mater. Res. Express 2018, 5, 026515. [CrossRef]

29. Butrymowicz, D.B.; Manning, J.R.; Read, M.E. Diffusion in Copper and Copper Alloys, Part II. Copper-Silver and Copper-Gold Systems. J. Phys. Chem. Ref. Data 1974, 3, 527-602. [CrossRef]

30. Adorno, A.T.; Beatrice, C.R.S.; CILENSE, M.; Petroni, I.A.; Hara, A.H. Influence of silver additions on the recrystallization kinetics of the Cu-5wt.\%Al alloy. Eclética Química 2000, 25, 51-61. [CrossRef]

Publisher's Note: MDPI stays neutral with regard to jurisdictional claims in published maps and institutional affiliations.

(C) 2020 by the authors. Licensee MDPI, Basel, Switzerland. This article is an open access article distributed under the terms and conditions of the Creative Commons Attribution (CC BY) license (http://creativecommons.org/licenses/by/4.0/). 